\title{
Structural and Functional Analysis of Nitrogenase Fe Protein with MgADP bound and Amino Acid Substitutions
}

\author{
Mi Suk Jeong and Se Bok Jang*
}

Korea Nanobiotechnology Center, Pusan National University, Jangjeon-dong, Keumjeong-gu, Busan 609-735, South Korea

Received August 4, 2004 / Accepted September 14, 2004

\begin{abstract}
The function of the [4Fe-4S] cluster containing iron (Fe-) protein in nitrogenase catalysis is to serve as the nucleotide-dependent electron donor to the MoFe protein which contains the sites for substrate binding and reduction. The ability of the Fe protein to function in this manner is dependent on its ability to adopt the appropriate conformation for productive interaction with the MoFe protein and on its ability to change redox potentials to provide the driving force required for electron transfer. The MgADP-bound (or off) conformational state of the nitrogenase Fe protein structure described reveals mechanisms for long-range communication from the nucleotide-binding sites to control affinity of association with the MoFe protein component. Two pathways, termed switches I and II, appear to be integral to this nucleotide signal transduction mechanism. In addition, the structure of the MgADP bound Fe protein provides the basis for the changes in the biophysical properties of the [4Fe-4S] observed when Fe protein binds nucleotides. The structures of the nitrogenase Fe protein with defined amino acid substitutions in the nucleotide dependent signal transduction pathways of the Switch I and Switch II have been determined by X-ray diffraction methods. These two pathways have been also implicated by site directed mutagenesis studies, structural analysis and analogies to other proteins that utilize similar nucleotide dependent signal transduction pathways. We have examined the validity of the assignment of these pathways in linking the signals generated by MgATP binding and hydrolysis to macromolecular complex formation and intermolecular electron transfer. The results provide a structural basis for the observed biophysical and biochemical properties of the Fe protein variants and interactions within the nitrogenase Fe protein-MoFe protein complex.
\end{abstract}

Key words - Fe protein, [FeS] Cluster, Nucleotide, Amino acid substitutions

The biological nitrogen fixation is catalyzed by the nitrogenase enzyme system which consists of two metalloproteins, the iron (Fe-) protein and the molybdenum-iron (MoFe-) protein $[4,6,14,27,31,39]$. During catalysis, these two components act to transfer electrons from the Fe-protein to the MoFe-protein, where substrate reduction occurs. This process involves the hydrolysis of two MgATP molecules per electron transferred in a reaction that can be represented by the following limiting stoichiometry [38]:

$\mathrm{N}_{2}+8 \mathrm{H}^{+}+16 \mathrm{MgATP}+8 \mathrm{e}^{-} \rightarrow 2 \mathrm{NH}_{3}+\mathrm{H}_{2}+16 \mathrm{MgADP}+16 \mathrm{Pi}$

Nucleotides bind to the homodimeric Fe protein, which also contains a single [4Fe-4S] cluster. One function of $\mathrm{MgATP}$ binding and hydrolysis is to regulate the transfer of an electron from the $[4 \mathrm{Fe}-4 \mathrm{~S}]$ cluster to the MoFe protein. The ultimate acceptor of electrons in the MoFe protein is a mixed metal cluster called FeMo-cofactor, where substrates bind and are reduced [37]. Following

\footnotetext{
*Corresponding author

Tel : +82-51-510-2523, Fax : +82-51-581-2546

E-mail : sbjang@pusan.ac.kr
}

each electron transfer event, the Fe protein dissociates from the MoFe protein, and the oxidized Fe protein is reduced concomitant with the replacement of the MgADP molecules by MgATP [12]. The hydrolysis of MgATP to MgADP appears to regulate the affinity for association between the Fe protein and the MoFe protein. This is essential to the reaction since all substrate reduction reactions catalyzed by nitrogenase require two or more electrons.

The majority of proteins containing [FeS] clusters have been shown to function in electron transfer. The midpoint potential of these [FeS] clusters controls both the thermodynamics and kinetics of the electron transfer reactions. Therefore, understanding the elements of the protein environment that dictate the properties of the bound [FeS] cluster is of significant fundamental importance [21,41]. Unique to this class of proteins is the nitrogenase $\mathrm{Fe}$ protein in which the magnitude of the midpoint potential can be controlled through conformation states of the protein dictated by its interaction with nucleotides and its specific electron acceptor. In the nitrogenase system, these 
conformational changes result in productive $\mathrm{Fe}$ proteinMoFe protein complex formation leading to electron transfer from the [4Fe-4S] cluster of the Fe-protein to the substrate reduction site of the MoFe-protein. It has been demonstrated previously that nucleotide binding and subsequent $\mathrm{Fe}$ protein-MoFe protein complex formation results in negative shifts in the midpoint potential of the [4Fe-4S] cluster of the Fe protein increasing the driving force for electron transfer to substrate reduction $[22,40$, $44,46]$. Nucleotide binding causes changes in the midpoint potential and other biophysical properties of the [4Fe-4S] of the Fe protein presumably by remotely triggering changes in the protein environment around the cluster [22,23,26,29, $33,40,42,44,46]$. Examination of the three-dimensional structures of proteins containing [ $4 \mathrm{Fe}-4 \mathrm{~S}$ ] clusters has suggested that the polarity around the [4Fe-4S] clusters of these proteins contributes to defining the midpoint potential of the cluster $[1,2,7,13,20,21,41]$. Some important factors in defining the polarity of the cluster environment are solvent accessibility, proximity of main chain amide dipoles, and the composition of amino acid side chains in the environment.

As is common among the general class of nucleotide utilizing proteins, MgATP acts at a distance to accomplish these changes in the nitrogenase mechanism [11]. Nucleotides bind to the Fe protein over $15 \AA$ away from the clusters involved in electron transfer and the protein surfaces involved in Fe protein-MoFe protein docking. This architecture for the Fe protein demands that the energy of nucleotide binding and hydrolysis be manifested as protein conformational changes that are communicated to the [4Fe-4S] cluster and to the protein-protein docking surface. A working model is that a continuum of protein conformational changes is dictated by the binding of MgATP, the hydrolysis of $\mathrm{Pi}$, the loss of $\mathrm{Pi}$, the repositioning of $\mathrm{Mg}^{2+}$ ion, and finishing with the MgADP bound or off state. In an effort to understand the nature of the nucleotide induced protein conformational changes and how these impact the nitrogenase mechanism, the crystal structure of the Fe protein in a MgADP bound state was determined by X-ray diffraction methods [17]. This structure, in conjunction with an earlier structure of the Fe proteinMoFe protein complex trapped with ADP $-\mathrm{AlF}_{4}^{-}$, provides insights into how specific regions of the Fe protein might act to transduce nucleotide interactions to changes in metal clusters and the association between the nitrogenase component proteins [36].
Further analysis of the determinants for conformational change associated with MgADP and MgATP interactions will provide key pieces of information relevant to the interactions between the Fe protein and MoFe protein that result in complex formation and trigger MgATP hydrolysis and electron transfer within the complex. In an effort to explore the conformational changes associated with nucleotide interaction, the structures of two nitrogenase Fe protein variants have been determined using $X$-ray diffraction methods [18]. These $\mathrm{Fe}$ proteins have defined substitutions that alter nucleotide interactions and nucleotide dependent conformational change. The variants have been previously characterized biochemically having Asp at position 39 substituted by Asn (Asp39Asn) and Asp 129 substituted by Glu (Asp129Glu). Previously Asp 39 and Asp 129 have been implicated by mutagenesis studies to participate in nucleotide interactions. Substitution of Asp 39 by Asn results in an altered Fe protein that is unable to dissociate from the MoFe protein subsequent to MgATP hydrolysis and electron transfer [24]. The biochemical characterization of an Fe protein variant with Asp129 substituted by Glu suggests that the variant is trapped in conformation that resembles the MgADP bound state in the absence of bound nucleotides [25]. In order to further understand the role of Phe 135 in Fe protein function and nitrogenase catalysis, we have determined the crystal structure of the nitrogenase Fe protein with Phe at position 135 substituted by $\operatorname{Trp}$ in its nucleotide free form [19]. The results establish a structural basis for the changes in midpoint potential of the [4Fe-4S] cluster. Comparisons of available Fe protein structures allow consideration of factors that contribute to coupling protein conformational changes in the [4Fe-4S] cluster environment with defined changes in the midpoint potential of the cluster. The $\mathrm{Fe}$ protein structures described herein provide a structural basis for the observed altered biochemical properties of the these interesting Fe protein site-direct variants. We have determined the $X$-ray crystal structure of the nitrogenase Fe protein with Phe at position 135 substituted by Trp in a MgADP state, establishing a structural basis for the changes in midpoint potential of the [4Fe-4S] cluster [18]. This structure gives important insights into the nature of the nucleotide induced protein conformational changes and provides an opportunity to differentiate the individual contributions arising from nucleotide binding in the signal transduction pathway within the Fe protein. 


\section{Role of the Nitrogenase Fe protein}

During the biological conversion of nitrogen to ammonia, the nitrogenase Fe protein participates as the exclusive electron donor to the MoFe protein where substrate reduction occurs [5,31]. The earth's atmosphere is composed of approximately $80 \%$ nitrogen. Almost all life forms require a fixed or combined form of nitrogen for growth. Nitrogen fixation is the process by which atmospheric nitrogen is reduced to ammonia, which can be assimilated by higher plants. Biological nitrogen fixation occurs among a physiologically diverse group of prokaryotic organisms.

Coupling the energy of nucleoside triphosphate binding and hydrolysis to conformational changes is a common mechanism for a number of proteins with disparate cellular functions including those involved in DNA replication, protein synthesis, and cell differentiation. Unique to this class of proteins is the dimeric Fe protein component of nitrogenase in which the binding and hydrolysis of MgATP controls intermolecular electron transfer and reduction of nitrogen to ammonia. Numerous proteins, with cellular functions ranging from cell division to molecular motion, couple the energy from the binding or hydrolysis of nucleoside triphosphates (e.g., ATP or GTP) to drive protein conformational changes. These protein conformational changes are often propagated over some distance $(>10 \AA)$ to activate a downstream function in the cell or to define an "on" or "off" state of the protein. The bacterial enzyme nitrogenase is a unique member of this class of nucleotide utilizing enzymes coupling the energy of nucleotide binding and hydrolysis to electron transfer reactions within a macromolecular complex.

\section{Fe protein Structure}

The Fe protein subunits are encoded by nifH, whose deduced amino acid sequence indicates that each subunit contains 298 amino acids, resulting in a single subunit product molecular mass of $32 \mathrm{kDa}[3,16]$. The Fe protein is a dimer of identical subunits bridged by a single $\mathrm{Fe}_{4} \mathrm{~S}_{4}$ cubane. The $\mathrm{Fe}_{4} \mathrm{~S}_{4}$ cluster is symmetrically coordinated by two cysteine residues from each subunit at amino acid 97 and 132 of the primary sequence and is located the axis of twofold symmetry (Fig. 1 and 2a). The two MgADP molecules bound to the Fe protein are located near the dimer interface, one on each subunit (Fig. 1 and 2b). The nucle-

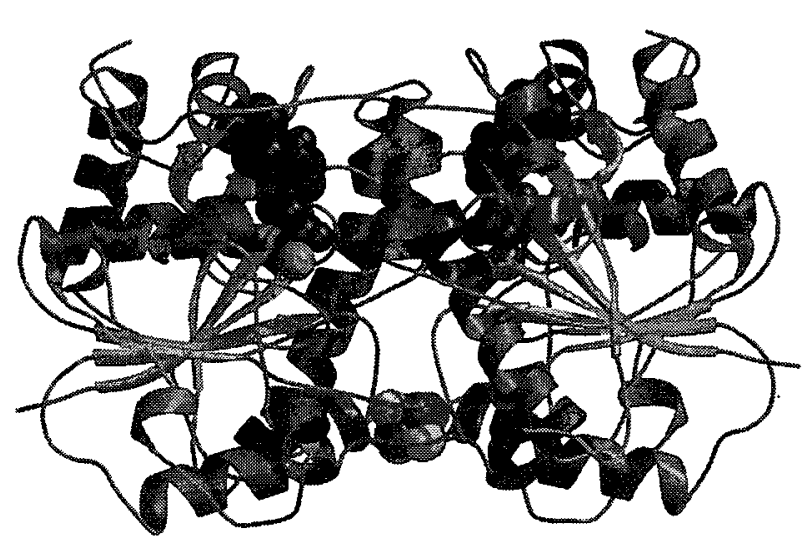

Fig. 1. Topology diagram of the MgADP bound Fe protein dimer. The [4Fe-4S] cluster is shown in a space-filling representation and the $\mathrm{MgADP}$ molecules are represented by ball-and-stick. Each Fe-protein monomer adopts a mixed $a$-helix $/ \beta$-sheet topology and $\beta$-strands (shown in pink) surrounded a-helices (shown in blue). The [4Fe-4S] cluster lies at one edge of the dimer interface; iron atoms are indicated in red, and sulfur atoms are in yellow. The non-crystallographic 2-fold axis runs vertically between the subunits in the plane of the page. The Fe protein is bound to two MgADP molecules per dimer. MgADP molecules are colorcoded with $\mathrm{C}$ in gray, $\mathrm{O}$ in red, $\mathrm{N}$ in blue, $\mathrm{P}$ in purple and $\mathrm{Mg}^{2+}$ ion in orange.

otide molecules are oriented : parallel to the two-fold symmetry axis with the b-phosphates pointing in the direction of the [4Fe-4S] cluster. Nucleotides bind to the Fe protein over $15 \AA$ away from the clusters involved in electron transfer and the protein surfaces involved in $\mathrm{Fe}$ protein-MoFe protein docking. This architecture for the Fe protein demands that the energy of nucleotide binding and hydrolysis be manifested as protein conformational changes that are communicated to the [4Fe-4S] cluster and to the protein-protein docking surface. These changes are likely indicative of a repositioning of the $\mathrm{Fe}_{4} \mathrm{~S}_{4}$ to effect productive electron transfer to the MoFe protein.

\section{Signal Transduction Pathways}

Switch I region is from 36 amino acid to 69 amino acid and switch II regions are residues 98-101 and 125-135. Aspartate at position 39 has been implicated as being a residue of Switch I and the Asp129 forms a part of the switch II region (residues 125-132). The site of the substitution at position 135 is very close to the Cys 132 coordinating ligands of the [4Fe-4S] cluster. The P-loop (phosphate-binding loop), residues 9-16, wraps around the 
a)

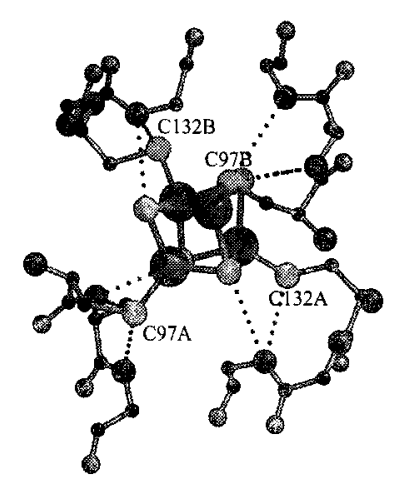

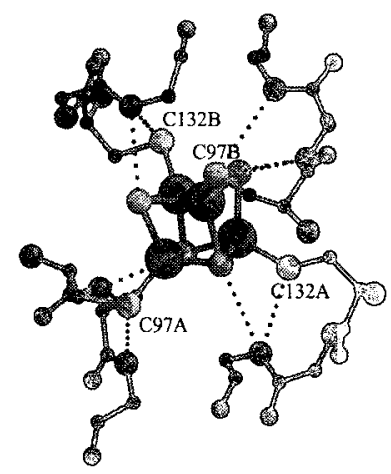

b)
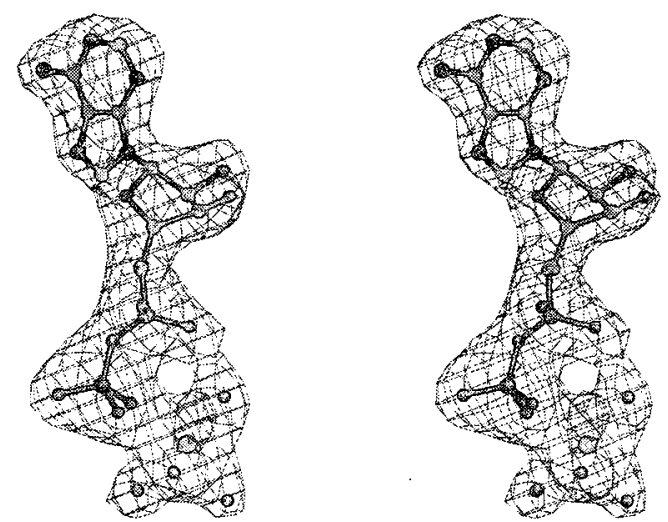

Fig. 2. Stereoviews of: a) Ball and stick diagram of the coordination environment of the [4Fe-4S] cluster of the iron protein. The color scheme includes Fe represented in rust, sulfur in yellow, oxygen in red, nitrogen in blue, and carbon in black. b) Fo-Fc difference electron density maps contoured at $3.5 \sigma$ in which the MgADP and associated water molecules are omitted from the structure factor and phase calculation.

phosphates of $\mathrm{ADP} . \mathrm{Mg}^{2+}$ ion is complexed by the side chain oxygens of protein and an ADP oxygens on the $\beta$ -phosphate. Switch I provides a mechanism for communication from the nucleotide-binding site to the Fe protein surface involved in interactions with the MoFe proteins (Fig. 3). It appears that the hydrolysis of MgATP to MgADP decreases the affinity of the Fe protein for the MoFe protein following electron transfer, thus allowing the two proteins to dissociate $[9,24,32]$. Switch I provides a mechanism for propagation of the change from the MgATP bound state to the MgADP state to the surface of the Fe protein to control protein-protein interaction. Switch II provides a mechanism for communication between the nucleotide-binding site and the [4Fe-4S] cluster (Fig. 3) [34, 45]. Superposition of the nucleotide-free $\mathrm{Fe}$ protein structure upon that of the MgADP Fe protein in the environment of the $[4 \mathrm{Fe}-4 \mathrm{~S}]$ cluster shows that the Cys132 ligands of the cluster experience a change in conformation while the Cys97 ligands remain largely unchanged (Fig. 2a). Binding of MgADP exerts small changes on the conformation of the P-loop regions that are in turn communicated to the cluster through a hydrogen bonding interaction of the main chain amide of Gly14 to the side chain of Asp129 (Fig. 3). Interestingly, substitution of Asp129 by Glu results in an Fe protein that in its nucleotide free state has similar biophysical properties of the native $\mathrm{Fe}$ protein with bound nucleotides [25]. This is in contrast to the Fe protein in the nitrogenase complex stabilized with MgADP and tetrafluoroaluminate in which the environment of all four ligands of the [4Fe-4S] cluster adopt

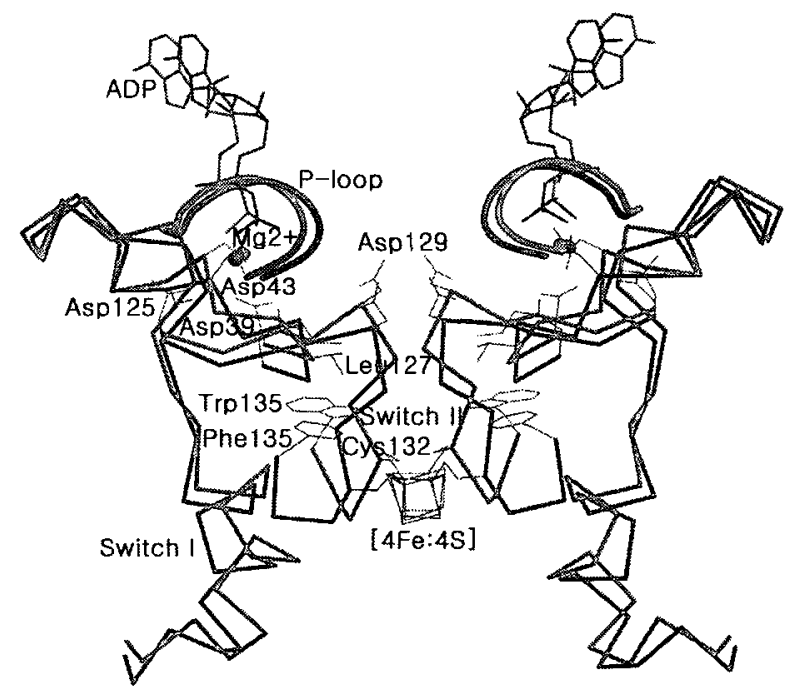

Fig. 3. a) The superposition of switches I, II and P-loop for the Phe135Trp Fe protein structure with MgADP bound (green) and Fe protein with MgADP bound (red). The side chains of several amino acid residues are shown, along with MgADP. In the F135W with MgADP bound structure, the conformational changes of this structure are remarkable than native with MgADP bound structure around the nucleotide binding region (P-loop), $4 \mathrm{Fe}-4 \mathrm{~S}$ cluster, switch II region and docking surface for interaction with the MoFe-protein (switch I).

different conformations [36]. The individual contributions of nucleotide binding and complex formation on the changes in the environment of the [4Fe-4S] cluster represents an elegant mechanism by which the biophysical properties of the cluster can be regulated during enzyme catalysis. 


\section{Nucleotide Interactions}

In the presence of MgADP or MgATP, the Fe protein undergoes conformational changes that result in changes in the midpoint potential and spectroscopic properties of the $[4 \mathrm{Fe}-45]$ cluster $[22,23,26,29,33,40,42,44,46]$. In addition, the $[4 \mathrm{Fe}-4 \mathrm{~S}$ ] cluster of the MgATP bound form of the $\mathrm{Fe}$ protein becomes more susceptible to specific metal chelators $[28,43]$. It is generally thought that the conformational changes result in a rigid body reorientation of the $\mathrm{Fe}$ protein monomers with respect to one another closing the dimer interface. This rigid body reorientation is observed in the nitrogenase $\mathrm{Fe}$ protein-MoFe protein complex stabilized with tetrafluoroaluminate and MgADP (Fig. 4a and b) [36]. The results of small angle $X$-ray scattering studies are also in support of a similar rigid body reorientation of the monomers in the presence of MgATP but in the absence of the MoFe protein [8]. These conformational changes are critical to the productive interaction of the Fe protein with the MoFe protein in order to bring about MgATP hydrolysis and electron transfer to substrates $[5,15,31]$. Entry of the MgADP molecules to the two binding sites on the Fe protein appears to be from the face opposite the [4Fe-4S] cluster (Fig. 1). Channels leading to the MgADP binding sites terminate in a region with significant negative charge. The majority of the negative charges come from three aspartate residues (Asp39, Asp43, and Asp125) that participate in the coordination of the $\mathrm{Mg}^{2+}$ ion either directly or through bound water molecules (Fig. $5 \mathrm{a}, \mathrm{b}$ and $\mathrm{c}$ ). The extent of the channel is clearly large enough for MgADP molecules to freely access the site in the MgADP bound state of the protein (Fig $4 \mathrm{~b}$, left panel). This contrasts with a decrease in access observed in the nitrogenase complex stabilized in the presence of $\mathrm{MgADP}$ and tetrafluoroaluminate (Fig. $4 \mathrm{~b}$, right panel) [36]. The closure of the channel in the $\mathrm{Fe}$ protein-MoFe protein complex results from a dramatic rigid body reorientation of the Fe protein subunits with respect to one another, bringing the subunit interface of the Fe protein monomers closer together.

\section{Amino Acid Substitutions}

The Trp substituted Fe protein variant is unable to a)

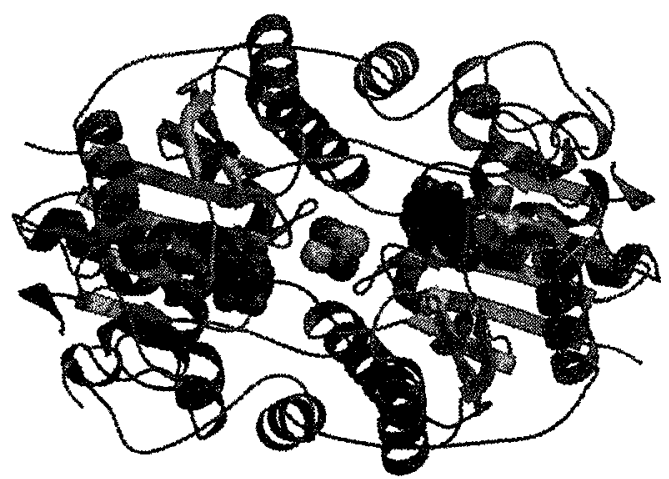

b)

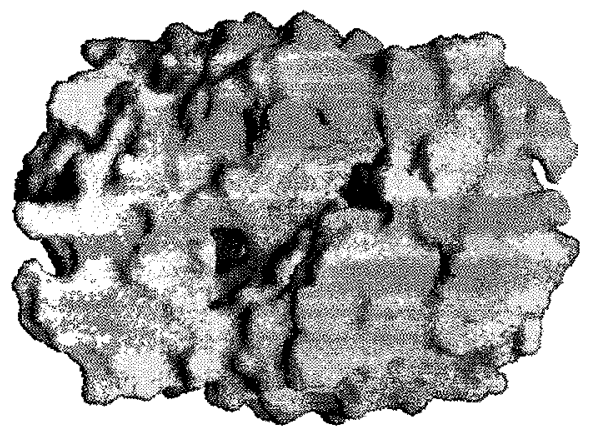

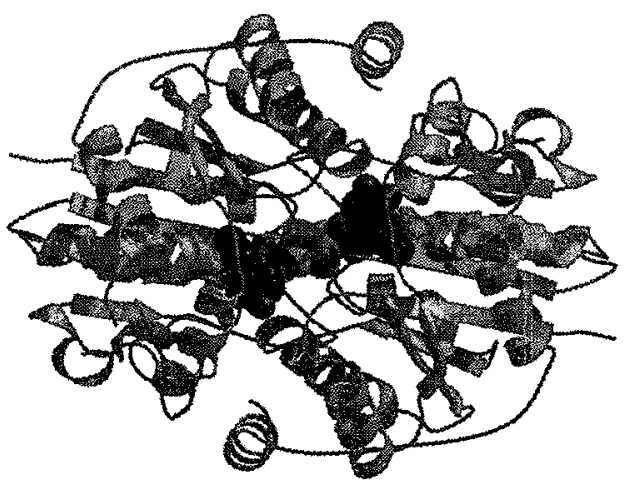

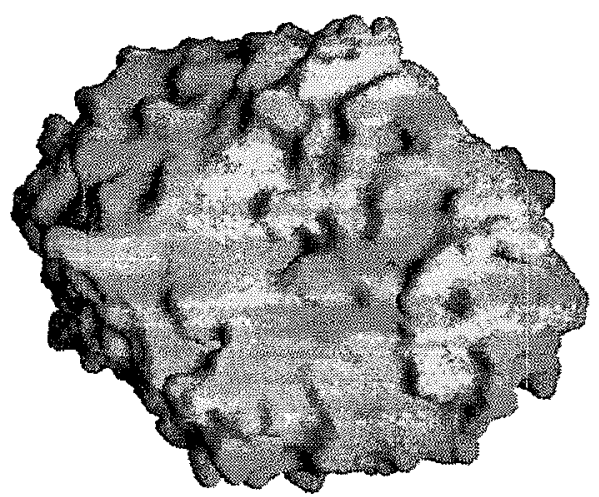

Fig. 4. Structure of nitrogenase Fe protein with MgADP or MgADP.AlF ${ }_{4}^{-}$bound. a) Topology diagram of the Fe protein with $\mathrm{MgADP}$ bound (left) or $\mathrm{MgADP}-\mathrm{AlF}_{4}$ (right) viewed from the top b) Surface representation of the Fe protein with MgADP bound (left) or MgADP- AlF $_{4}^{-}$(right) viewed from the top with MgADP molecules shown in red. 
a)

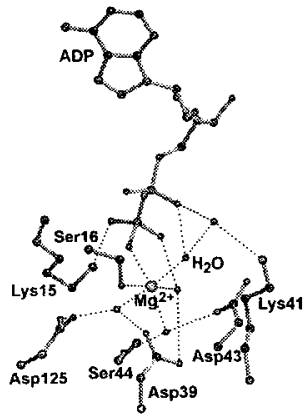

b)

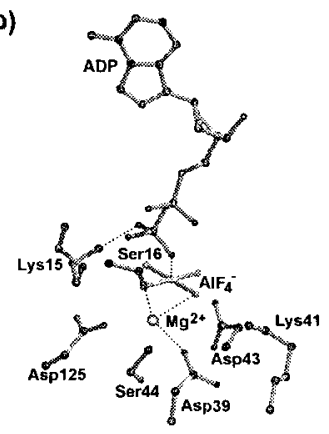

c)

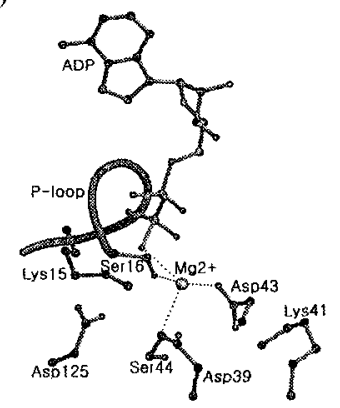

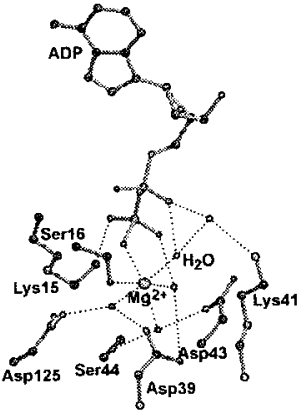
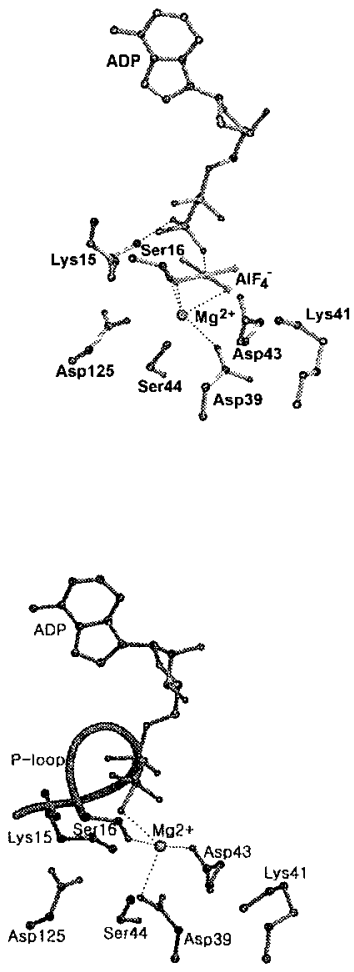

Fig. 5. Protein interactions with the phosphate region. a) Wall-eyed stereoview of the region of the Fe protein within a single subunit coordinating the phosphates of the ADP and the $\mathrm{Mg}^{2+}$ ion (orange) coordination in the $\mathrm{MgADP}$ bound Fe protein and $\mathrm{b}$ ) the Fe protein with the nitrogenase complex stabilized by $\mathrm{MgADP}-\mathrm{AlF}_{4}{ }^{\circ}$. c) In the MgADP-bound F135W Fe protein, the tetrahedral coordination environment of the $\mathrm{Mg}^{2+}$ consists of one bound $\beta$-phosphate, the side chain oxygen atoms of Asp39, Asp43, and Ser16. The P-loop regions are shown as coil models (magenta).

productively interact with the MoFe protein or bring about MgATP hydrolysis or electron transfer. Examination of the structure of the Trp substituted variant indicates that the regions of the $\mathrm{Fe}$ protein presumed to be involved in nucleotide interactions appear to be unaffected by the substitution. Of course, it is impossible to say whether these interactions may be altered in a MgATP bound state, however, the Trp substituted variant exhibits similar affinities for MgADP and MgATP. A more straightforward interpretation of the inability of this Fe protein to act in catalysis is the inability of the Fe protein variant to achieve the extent of conformational changes necessary for a productive interaction with the MoFe protein. Although conformational changes are undoubtedly imposed on the MgATP bound Fe protein upon interaction with the MoFe protein it is generally thought that the conformational changes brought about by MgATP binding alone are along the lines of those observed in the nitrogenase complex. Extrapolation of the conformation changes observed in the Fe protein when complexed with the MoFe protein in the MgADP and tetrafluoroaluminate stabilized complex on the Trp substituted Fe protein variant suggest that the bulkier Trp group would prevent the extent of conformational changes observed in the complex (Fig. 3) [36]. In the nitrogenase complex Phe 135 is involved in a tightly packed group of hydrophobic residues located at the face of the $[4 \mathrm{Fe}-4 \mathrm{~S}]$ cluster distal to the Fe protein-MoFe protein docking interface. The above extrapolation also would suggest that the amide $\mathrm{N}$ of Trp would approach the cluster even more closely than in the nucleotide free state observed which would be consistent with a positive shift in the midpoint potential upon MgATP binding. This is counter to the previous observations that indicate a negative shift in the midpoint potential upon MgATP binding to the $\operatorname{Trp}$ substituted variant (Fig. 5c) [34]. This may indicate that this type of extrapolation does not mimic the specific changes brought about by the binding of nucleotide alone or the contributions of the orientation and distance of the helix dipoles are much more significant in modulating the midpoint potential of the $[4 \mathrm{Fe}-4 \mathrm{~S}]$ cluster of the Fe protein.

Aspartate at position 39 has been implicated as being a key residue of Switch I thereby having a role in communicating the signals from the binding and hydrolysis of MgATP to the Fe protein-MoFe protein docking interface to facilitating subsequent complex formation. Similarly aspartate at position 129 is thought to be important in the communication through the Switch II region between the individual sites for MgATP binding and hydrolysis to effect changes on the biochemical and biophysical properties of the [FeS] cluster. Amino acid substitution studies at position 39 and 129 support these assertions. In an effort 
to further our understanding of the conformational changes associated with nucleotide binding that lead to complex formation and electron transfer, the structures of the nitrogenase $\mathrm{Fe}$ protein variants with Asp at position 39 substituted by Asn (Asp39Asn), 129 substituted by Glu (Asp129Glu), and Asp39Asn with MgADP bound have been determined. The results provide a structural basis for the observed biophysical and biochemical properties of the Fe protein variants and interactions within the nitrogenase Fe protein-MoFe protein complex. The figures were generated using the programs BOBSCRIPT and GRASP $[10,30]$.

\section{Comments}

The structure of the MgADP state provides an opportunity to differentiate the individual contributions arising from nucleotide binding, nitrogenase complex formation, and complex dependent nucleotide hydrolysis in the catalytic mechanism of this complex enzyme. In addition, the structure provides the basis for the changes in the biophysical properties of the [4Fe-4S] observed when Fe protein binds nucleotides. The structure of the MgADP bound $\mathrm{Fe}$ protein provides important insights into the respective contributions of nucleotide interaction and complex formation in defining the conformational states that are the keys to nitrogenase catalysis. The culmination of the structure of the Trp substituted Fe protein variant together with detailed comparisons of the available Fe protein structures, have led to a reevaluation of the factors which dictate the changes in midpoint potentials of the [4Fe-4S] cluster upon nucleotide binding and complex formation. Conformational changes that drive the orientation and proximity of helix dipoles with respect to the [4Fe-4S] cluster of the $\mathrm{Fe}$ protein presents an elegant mechanism by which large changes in the midpoint potential can be modulated. Studies on forms of the $\mathrm{Fe}$ protein altered at the Phe 135 site have revealed an important role for Phe 135 in defining both the spectroscopic properties and the nucleotide-induced changes in the redox potential of the $4 \mathrm{Fe}-4 \mathrm{~S}$ cluster. In the $\mathrm{F} 135 \mathrm{~W}$ with MgADP bound structure, the conformational changes of this structure are remarkable than other native structures around the nucleotide-binding region, [4Fe-4S] cluster, and docking surface for interaction with the MoFe-protein. It is thought that the conformational changes result in a rigid body reorientation of the Fe protein monomers with respect to one another closing the dimer interface. These conformational changes are critical to the productive interaction of the $\mathrm{Fe}$ protein with the MoFe protein in order to bring about MgATP hydrolysis and electron transfer to substrates. In both Asp39Asn and Asp39Asn. MgADP bound structures, the primary polar interactions linking these two regions between switch I (Asn39) and switch II (Asp125) are the hydrogen bonds between Asn39 and Asp125. These results may suggest that the affinity of the Fe protein for the MoFe protein is increased and the Fe protein did not dissociate after electron transfer. Also, the $\mathrm{Mg}^{2+}$ coordination environment in the Asn39 with MgADP bound is different from the wild type in the MgADP state such that the communication pathway to docking interface can be perturbed in some manner such that dissociation is affected. The Glu129 residue is in the interaction of the side chain with the P-loop and the extra carbon added in the Glu for Asp substitutions mimics somewhat the effects that nucleotides exert on the P-loop that is transferred to switch II via this specific interaction. The characteristics of this protein explain the structural implications that those are the increase in the MgATP binding and the Asp129Glu mutant possesses properties of the MgADP state in the absence of MgADP. The specific interaction of the Glu129 on the P-loop mimicking the interactions of the MgADP phosphates is opening up of the site for easier MgATP binding.

\section{Acknowledgments}

This work was supported by Pusan National University Research Grant to SBJ.

\section{References}

1. Adman, E., Watenpaugh, K. D., and Jensen, L. H. 1975. $\mathrm{NH}-\mathrm{S}$ hydrogen bonds in Peptococcus aerogenes ferredoxin, Clostridium pasteurianum rubredoxin, and Chromatium high potential iron protein. Proc. Natl. Acad. Sci. USA 72, 4854-4858.

2. Breiter, D. R., Meyer, T. E., Rayment, L., and Holden, H. M. 1991. The molecular structure of the high potential iron-sulfur protein isolated from Ectothiorhodospira halophila determined at 2.5-A resolution. J. Biol. Chem. 266, 18660-18667.

3. Brigle, K. E.; Newton, W. E.; Dean, D. R. 1985. Complete nucleotide sequence of the Azotobacter vinelandii nitrogenase structural gene cluster. Gene 37, 37-44. 
4. Burgess, B. K. 1984. In advances in nitrogen fixation. pp. 103-114, In Veeger, C. and Newton, W. E. (eds.), Martinus Nijhoff, Boston.

5. Burgess, B. K. and Lowe, D. J. 1996. Mechanism of molybdenum nitrogenase. Chem. Rev. 96, 2983-3011.

6. Burris, R. H. (1991) Nitrogenases. J. Biol. Chem. 266, 9339-9342.

7. Carter, C. W., Jr., Kraut, J., Freer, S. T., Xuong, N. H., Alden, R. A., and Bartsch, R. G. 1974. Two-Angstrom crystal structure of oxidized Chromatium high potential iron protein. J. Biol. Chem. 249, 4212-4225.

8. Chen, L., Gavini, N., Tsuruta, H., Eliezer, D., Burgess, B. K., Doniach, S., and Hodgson, K. O. 1994. MgATP-induced conformational changes in the iron protein from Azotobacter vinelandii, as studied by small-angle $x$-ray scattering. J. Biol. Chem. 269, 3290-3294.

9. Duyvis, M. G., Wassink, H., and Haaker, H. 1996. Formation and characterization of a transition state complex of Azotobacter vinelandii nitrogenase. FEBS Lett. 380, 233-236.

10. Esnouf, R. M. 1997. An extensively modified version of MolScript that includes greatly enhanced coloring capabilities. J. Mol. Graph Model. 15, 132-134.

11. Georgiadis, M. M., Komiya, H., Chakrabarti, P., Woo, D., Kornuc, J. J., and Rees, D. C. 1992. Crystallographic structure of the nitrogenase iron protein from Azotobacter vinelandii. Science 257, 1653-1659.

12. Hageman, R. V., and Burris, R. H. 1978. Nitrogenase and nitrogenase reductase associate and dissociate with each catalytic cycle. Proc. Natl. Acad. Sci. U.S.A. 75, 2699-2702.

13. Heering, H. A., Bulsink, Y. B. M., Hagen, W. R., and Meyer, T. E. 1995. Reversible super-reduction of the cubane $[4 \mathrm{Fe}-4 \mathrm{~S}](3+; 2+; 1+)$ in the high-potential iron-sulfur protein under non-denaturing conditions. EPR spectroscopic and electrochemical studies. Eur. T. Biochem. 232, 811-817.

14. Howard, J. B. and Rees, D. C. 1994. Nitrogenase: a nucleotide-dependent molecular switch. Annu. Rev. Biochem. 63, 235-264.

15. Howard, J. B., and Rees, D. C. 1996. Structural Basis of Biological Nitrogen Fixation. Chem. Rev. 96, 2965-2982.

16. Jacobson, M. R.; Brigle, K. E.; Bennett, L. T., Setterquist, R. A.; Wilson, M. S., Cash, V. L., Beyon, J., Newton, W. E., Dean, D. R. 1989. Physical and genetic map of the major nif gene cluster from Azotobacter vinelandii. J. Bacteriol. 171, 1017-1027.

17. Jang, S. B., Seefeldt, L. C., and Peters, J. W. 2000. Insights into nucleotide signal transduction in nitrogenase: structure of an iron protein with MgADP bound. Biochemistry 39, 14745-14752.

18. Jang, S. B., Jeong, M. S., Seefeldt, L. C., Peters, J. W. 2004. Physical and genetic map of the major nif gene cluster from Azotobacter vinelandii. accepted to J. Biol. Inorg. Chem.

19. Jang, S. B., Seefeldt, L. C., and Peters, J. W. 2000. Modulating the midpoint potential of the $[4 \mathrm{Fe}-4 \mathrm{~S}]$ cluster of the nitrogenase Fe protein. Biochemistry 39, 641-648.

20. Jensen, G. M., Warshel, A., and Stephens, P. J. 1994. Calculation of the redox potentials of iron-sulfur proteins: the 2-/3-couple of [Fe4S 4 Cys4] clusters in Peptococcus aerogenes ferredoxin, Azotobacter vinelandii ferredoxin I, and Chromatium vinosum high-potential iron protein. Biochemistry 33, 10911-10924.

21. Langen, R., Jensen, G. M., Jacob, U., Stephens, P. J., and Warshel, A. 1992. Protein control of iron-sulfur cluster redox potentials. J. Biol. Chem. 267, 25625-25627.

22. Lanzilotta, W. N., and Seefeldt, L. C. 1997. Changes in the midpoint potentials of the nitrogenase metal centers as a result of iron protein-molybdenum-iron protein complex formation. Biochemistry 36, 12976-12983.

23. Lanzilotta, W. N., Holz, R. C., and Seefeldt, L. C. 1995. Proton NMR investigation of the $[4 \mathrm{Fe}-4 \mathrm{~S}] 1+$ cluster environment of nitrogenase iron protein from Azotobacter vinelandii: defining nucleotide-induced conformational changes. Biochemistry 34, 15646-15653.

24. Lanzilotta, W. N., Fisher, K., and Seefeldt, L. C. 1997. Evidence for electron transfer-dependent formation of a nitrogenase iron protein-molybdenum-iron protein tight complex. The role of aspartate 39.J. Biol. Chem. 272, 4157-65.

25. Lanzilotta, W. N., Ryle, M. J., and Seefeldt, L. C. 1995. Nucleotide hydrolysis and protein conformational changes in Azotobacter vinelandii nitrogenase iron protein: defining the function of aspartate 129. Biochemistry 34, 10713-10723.

26. Lindahl, P. A., Gorelick, N. J., Münck, E., and OrmeJohnson, W. H. 1987. EPR and Mossbauer studies of nucleotide-bound nitrogenase iron protein from Azotobacter vinelandii. J. Biol. Chem. 262, 14945-14953.

27. Mortenson, L. E., Seefeldt, L. C., Morgan, T. V. and Bolin, J. T. 1993. The role of metal clusters and MgATP in nitrogenase catalysis. Adv. Enzymol. Rel. Areas Mol. Biol. 67, 274-299.

28. Ljones, T. and Burris, R. H. 1978. Nitrogenase: the reaction between the Fe protein and bathophenanthrolinedisulfonate as a probe for interactions with MgATP. Biochemistry 17, 1866-1872.

29. Meyer, J., Gaillard, J., and Moulis, J. M. 1988. Hydrogen-1 nuclear magnetic resonance of the nitrogenase iron protein (Cp2) from Clostridium pasteurianum. Biochemistry 27, 6150-6156.

30. Nicholls, A., Sharp, K. A., and Honig, B. 1991. Protein folding and association: Insights from the interfacial and thermodynamic properties of hydrocarbons Proteins 11, 281-296.

31. Peters, J. W., Fisher, K., and Dean, D. R. 1995. Nitrogenase structure and function: A biochemical-genetic perspective. Annu. Rev. Microbiol. 49, 335-366.

32. Renner, K. A., and Howard, J. B. 1996. Aluminum fluoride inhibition of nitrogenase: stabilization of a nucleotide.Feprotein.MoFe-protein complex. Biochemistry 35, 5353-5358. 33. Ryle, M. J., Lanzilotta, W. N., Seefeldt, L. C., Scarrow, R. 
C., and Jensen, G. M. 1996. Circular dichroism and x-ray spectroscopies of Azotobacter vinelandii nitrogenase iron protein. MgATP and MgADP induced protein conformational changes affecting the [4Fe-4S] cluster and characterization of a [2Fe-2S] form. J. Biol. Chem. 271, 15511557.

34. Ryle, M. J. and Seefeldt, L. C. 1996. Elucidation of a MgATP signal transduction pathway in the nitrogenase iron protein: formation of a conformation resembling the MgATP-bound state by protein engineering. Biochemistry 35, $4766-4775$.

35. Ryle, M. J., Lanzilotta, W. N., and Seefeldt, L. C. 1996. Elucidating the mechanism of nucleotide-dependent changes in the redox potential of the [4Fe-4S] cluster in nitrogenase iron protein: the role of phenylalanine 135. Biochemistry 35, 9424-9434.

36. Schindelin, H., Kisker, C., Schtessman, J. L., Howard, J. B., and Rees, D. C. 1997. Structure of ADP AIF4(-)-stabilized nitrogenase complex and its implications for signal transduction. Nature 387, 370-376.

37. Shah, V. K., and Brill, W. J. 1977. Isolation of an ironmolybdenum cofactor from nitrogenase. Proc. Natl. Acad. Sci. U.S.A. 74, 3249-3253.

38. Simpson, F. B. and Burris, R. H. 1984. A nitrogen pressure of 50 atmospheres does not prevent evolution of hydrogen by nitrogenase. Science 224, 1095-1097.

39. Smith, B. E. and Eady, R. R. 1992. Metalloclusters of the nitrogenases. Eur. J. Biochem. 205, 1-15.
40. Spee, J. H., Arendsen, A. F., Wassink, H., Marritt, S. J., Hagen, W. R., and Haaker, H. 1998. Redox properties and electron paramagnetic resonance spectroscopy of the transition state complex of Azotobacter vinelandii nitrogenase. FEBS Lett. 432, 55-58.

41. Stephens, P. J., Jollie, D. R., and Warshel, A. 1996. Protein control of redox potentials of ironminus sign sulfur proteins. Chem. Rev. 96, 2491-2513.

42. Stephens, P. J., McKenna, C. E., Smith, B. E., Nguyen, H. T., McKenna, M. C., Thomson, A. J., Devlin, F., and Jones, J. B. 1979. Circular dichroism and magnetic circular dichroism of nitrogenase proteins. Proc. Natl. Acad. Sci. U.S.A. 76, 2585-2589.

43. Walker, G. A., and Mortenson, L. E. 1974. Effect of magnesium adenosine 5 -triphosphate on the accessibility of the iron of clostridial azoferredoxin, a component of nitrogenase. Biochemistry 13, 2382-2388.

44. Watt, G. D., Wang, Z. C., and Knotts, R. R. 1986. Redox reactions of and nucleotide binding to the iron protein of Azotobacter vinelandii. Biochemistry 25, 8156-8162.

45. Wolle, D., Dean, D. R., and Howard, J. B. 1992. Nucleotideiron-sulfur cluster signal transduction in the nitrogenase iron-protein: the role of Asp125. Science 258, 992-995.

46. Zumft, W. G., Palmer, G., and Mortenson, L. E. 1973. Electron paramagnetic resonance studies on nitrogenase. II. Interaction of adenosine 5 'triphosphate with azoferredoxin. Biochim. Biophys. Acta. 292, 413-421.

\title{
초록 : MgADP 결합 및 아미노산 치환 Nitrogenase $\mathrm{Fe}$ 단백질의 구조 및 기능 분석
}

\author{
정미숙, 장세복* \\ (부산대학교 한국나노바이오테크놀러지센터)
}

Nitrogenase 촉매에서 $\mathrm{Fe}$-단백질을 포함하는 [4Fe-4S] 클라스터의 기능은 기질의 결합과 환원 자리를 포함 하는 $\mathrm{MoFe}$-단백질로 핵산 의존 전자 주개로 작용하는 것이다. 이러한 방법의 $\mathrm{Fe}$-단백질의 기능은 $\mathrm{MoFe}$-단백 질과 상호작용을 위해 적합한 구조를 갖추며 전자 전달을 위한 추진력을 제공하기 위해 산화 환원 퍼텐셜을 변화시키는 능력에 의존한다. Nitrogenase $\mathrm{Fe}$-단백질에 $\mathrm{MgADP}$ 가 결합한 (혹은 떨어진) 구조적 정보는 핵산 결합 자리로부터 $\mathrm{MoFe}$-단백질과의 결합력을 조절하기위한 장거리 상호작용 메커니즘을 제시한다. 스위치 I과 $\mathrm{II}$ 의 두 가지 경로가 뉴클레오티드의 신호전달 메커니즘을 담당한다. $\mathrm{MgADP}$ 가 결합된 $\mathrm{Fe}$-단백질의 구조는 $\mathrm{Fe}$ 단백질이 핵산과 결합할 때 관찰되는 [4Fe-4S] 클라스터의 생물리학적 특성 변화의 기초를 제공한다. 스위 치, I과 II의 핵산 의존 신호전달 경로에서 특정 아미노산이 치환된 nitrogenase Fe-단백질의 구조들이 X-선 회절법에 의해서 결정되었다. 이들 경로는 아미노산 치환 연구, 구조 분석, 유사한 핵산 의존 신호전달 경로 에 이용된 다른 단백질 등에 의해서도 분석되었다. 이들 경로가 거대분자 착물 형성과 분자간 전자 전달을 위한 $\mathrm{MgADP}$ 결합과 가수분해의 신호전달 경로로의 타당성이 조사되었다. 이러한 결과는 nitrogenase $\mathrm{Fe}$ 단 백질과 $\mathrm{MoFe}$-단백질 착물에서 $\mathrm{Fe}$-단백질의 변이와 상호작용의 생물리학적 및 생화학적 특성을 위한 기초적 자료롤 제공할 것이다. 